\title{
EVALUATION OF PUBLIC OPINION REGARDING THE CHANGES IMPLEMENTED TO ENCOURAGE BICYCLE USE IN THE CITY OF SÃO PAULO
}

\section{AEvandro Luiz Lopes, BMarcelo Carvalho, CPaula Roberta Gomes Miranda}

\section{ARTICLE INFO}

\section{Article history:}

Received 25 September 2021

Accepted 25 November 2021

\section{Keywords:}

Bicycle

Urban Mobility

Public Policies

\section{ABSTRACT}

Purpose: To identify the main factors that make the population of a large metropolis a dhere to the use of bicycles as a option of transportation.

Method: Survey with 299 respondents analyzed by means of descriptive statistics and multiple linear regression.

Originality/Relevance: Unpublished study in relation to the inhabitants of the city of São Paulo and that can help in the elaboration of public policies that improve urban mobility.

Results: It was possible to identify that the greatest acceptance for the policies occurs by individuals more connected to public services and not with demographic factors.

Contributions: Individual factors that explain the propensity to adopt an alternative transportation system were identified.

Doi: https://doi.org/10.26668/businessreview/2022.v7i1.288

\footnotetext{
${ }^{A}$ Doctor in Business Administration from the Universidade Nove de Julho - UNINOVE, São Paulo (Brazil) and postdoctorate in BA from the Universidade Federal de Minas Gerais- UFMG, Minas Gerais (Brazil).

Email: elldijo@uol.com.br Orcid: https://orcid.org/0000-0002-2780-4215

B PhD candidate in Business Administration at Universidade Nove de Julho - UNINOVE, São Paulo (Brazil). Email: marcelocarvalho.gestor@gmail.com Orcid: https://orcid.org/0000-0003-2121-4318

${ }^{c}$ Business Administration from the Universidade Federal de São Paulo - UNIFESP, São Paulo (Brazil). Orcid: https://orcid.org/0000-0003-1320-3774
} 


\section{AVALIAÇÃO DA OPINIÃO PÚBLICA A RESPEITO DAS MUDANÇAS IMPLEMENTADAS PARA INCENTIVAR O USO DA BICICLETA NA CIDADE DE SÃO PAULO}

Objetivo principal: Identificar os principa is fatores que fazem a população de uma grande metrópole a derir a o uso de bicicletas como opção de transporte.

Método: Pesquisa com 299 entrevistados analisa dos por meio de estatísticas descritivas e regressão linear múltipla.

Originalidade/Relevância: Estudo inédito em relação aos habitantes da cidade de São Paulo e que pode ajudar na elaboração de políticas pública s que melhorem a mobilida de urbana.

Resultados: Foi possível identificar que a maior a ceitação das políticas ocorre por indivíduos mais liga dos a os serviços públicos e não a fatores demográficos.

Contribuições: Foram identificados fatores individuais que explicam a propensão a adotar um sistema alternativo de transporte.

Palavras-chave: Bicicleta; Mobilida de Urbana; Políticas Públicas.

\section{EVALUACIÓN DE LA OPINIÓN PÚBLICA SOBRE LOS CAMBIOS IMPLEMENT ADOS PARA FOMENTAR EL USO DE LA BICICLETA EN LA CIUDAD DE SÃO PAULO}

Objetivo principal: Identificar los principa les factores que hacen que la población de una gran metrópoli se adhiera al uso de la bicicleta como opción de transporte.

Método: Encuesta con 299 encuestados analiza da mediante estadística descriptiva y regresión lineal múltiple.

Originalidad/Relevancia: Estudio inédito en relación a los habitantes de la ciudad de São Paulo y que puede ayudar en la elaboración de políticas públicas que mejoren la movilidad urbana.

Resultados: Se pudo identificar que la mayor aceptación para las políticas se da por parte de los individuos más vinculados a los servicios públicos y no con factores demográficos.

Contribuciones: Se identificaron los factores individuales que explican la propensión a a doptar un sistema de transporte alternativo.

Palabras clave: Bicicleta; Movilidad Urbana; Políticas Públicas.

\section{Introduction}

The city of São Paulo has implemented several changes related to urban mobility. As one of the cities with the worst traffic congestion in Brazil, São Paulo citizens have been facing a chaotic traffic. This scenario is already part of the routine of a large part of the population (Lopes \& Santos, 2020) that lives or works in the city and that nowadays has the habit of measuring distances in time.

According to the National Policy of Urban Mobility - PNMU (Law 12,578 of 2012), municipalities with total population above 20,000 inhabitants must prepare and submit their 
Urban Mobility Plan in order to receive federal fund s that can assist in investments in this area (National Association of Urban Transport Companies, 2006). This law also provides for priority of non-motorized transport over individual motorized transport, regardless of the size of the Municipality (Ministério das Cidades, 2015).

It cannot be stated with certainty that the number of cars is the main cause of the chaos in the city's mobility. Other factors contribute to chaotic traffic and are related to the notion of urban space and how it is occupied, including the existing distance between home and work, the transportation systems themselves and the interaction between the components of urban mobility: human factor, vehicle, public road and environment. (Scaringella, 2001)

This logic leads us to think that the deficient analysis of the factors that contribute to the increase in congestion time in the city is the main cause of the mobility crisis experienced nowadays. The urban mobility crisis is "a technological, political and administrative challenge, which requires a more holistic and less sectorial treatment [...]" (Scaringella, 2001, p. 56). While the author states that one of the solutions to the problem is the rational use of existing infrastructure, Freitas et al. (2015) reinforces the concept of intermodality highlighting the bicycle as a modal with great potential, provided that there is structure that integrates it with other types of transport.

The growth of bicycle use in Brazil occurred in 1997, with the creation of a Law in the Brazilian Traffic Code, which inserted the bicycle as a protected means of transportation in urban traffic. In order to encourage bicycle use and increase cyclists' safety, the National Program of Mobility by Bicycle - Bicicleta Brasil was created in 2004, encouraging the states and municipalities to include bicycle transportation in a safe way and integrated with the existing transportation systems (Ministério das Cidades, 2015). Among the main benefits obtained with the use of the bicycle, one can highlight the low cost, non-emission of pollutant gases, contribution to reduce the noise of the road system, reduction of urban costs, and increased quality of life of users, combating sedentarism and obesity (Teschke et al., 2011; Ministério das Cidades, 2015; Rojas-Rueda, 2021).

In São Paulo, the incentive to bicycle use has grown in recent years. Part of this growth is due to actions at the national level, which encouraged municipalities to integrate this means of transportation to the others. The creation of cycle lanes on Sundays and holidays, expansion of the number of bike lanes in different regions of the city, implementation of bicycle rental, and more recently, the possibility of transporting bicycles on some city buses, are just some 
examples of improvements implemented with the goal of encouraging the population to explore other more sustainable (Fabris, Bernardy, Sehnem \& Piekas, 2020) means of transportation.

These changes aim to rationalize the use of public space, in order to maximize the use of space by the population and reduce the occupation of automobiles, the main polluting agents in the cities. According to the Urban Mobility Plan (PlanMob), the majority number of motor vehicles on urban roads increases the mobility problems of cities, especially when it comes to pollution and accidents, generating expenses for the government of almost $\mathrm{R} \$ 10$ billion per year (Ministério das Cidades, 2015).

In light of the mobility difficulties faced in the daily life of São Paulo citizens and of the changes implemented in the city aiming to improve this aspect, this paper aims to analyze the opinion of a sample of the population living or working in the city of São Paulo regarding the creation and expansion of bike lanes in the city. Specifically, it aims to: a) understand the population's assessment in light of the creation and expansion of bicycle and bike lanes in the city of São Paulo; b) identify the perceived quality of these bike lanes; c) identify the main reasons for not using the bicycle; and d) assess whether there is a relationship between approval of policies to create and expand bicycle and bike lanes with personal motivation for public services. With the results of this study, it is understood that it is possible to evaluate improvements in the implementation plan of bike lanes and cycle tracks, generating greater attractiveness and increasing the number of cyclists and the acceptance of the population for these changes. Therefore, the research question that will be addressed by this study can be defined as: to identify the population's evaluation regarding the incentive policy for bicycle use in the city of São Paulo / Brazil.

This article is structured, besides the introduction, as follows: theoretical framework, method, results analysis, discussion, and final considerations.

\section{Theoretical framework}

This topic describes the theoretical and empirical basis that covers the operation of the bicycle paths program in the city of São Paulo, presenting statistical data on the use of bicycle paths and their consequences, as well as showing a comparison with other cities in the world that are favorable to this means of transportation. 


\subsection{The bicycle paths program}

The use of bicycles as a means of transportation can minimize the harmful effects caused by the excess of motorized vehicles in the cities, bringing benefits to the individual and to the Society (Chen et al., 2020; Mao et al., 2021). Among the advantages observed in the adoption of the bicycle as a means of transportation, the following stand out: low environmental impact and low infrastructure cost (Olekszechen, Battiston, \& Kuhnen, 2016); it is more accessible, which provides greater social equality (Bacchieri et al., 2005); health benefits, such as lower risk of developing cardiovascular diseases and better cardiorespiratory fitness (Oja et al., 2011).

According to a case study conducted by an agency of the United States Department of Transportation (Federal Highway Administration - FHWA), the factors that influence individuals in their choices for this mode are divided into subjective factors, such as safety, cost, trip length, and objective factors, such as environmental factors and infrastructure characteristics (Goldsmith, 1992). Among the subjective factors, physical activity is the most prevalent factor for bicycling, indicating that bicyclists are clearly concerned with health benefits (Sener, Eluru, \& Bhat, 2009). Safety is the subjective factor that contributes the most to not adopting the bicycle (Silva et al., 2005). With regard to objective factors, a determining aspect is improved bicycle facilities at the workplace and along bicycle paths (Sener, Eluru, \& Bhat, 2009).

According to research conducted by the Institute for Transportation \& Development Policy - IDTP (2015), regulation and enforcement alone are not enough to ensure cyclists' safety. It would be necessary to work mainly on the infrastructure of roads, increasing sidewalks and improving signaling of bike lanes. Another relevant factor is the integration between bicycles and other means of transportation, such as subway and train. The construction of bike racks in subway stations, train stations, and bus terminals encourages the use of bicycles as a means of transportation (Freitas et al., 2015).

The city of São Paulo observes this intermodal interaction. The city has 473.4 kilometers of bike lanes/cycle paths, 75 public bike racks, and 7,980 bicycle spaces (CET, 2020). The integration of bicycles with public transportation systems is also already offered in the city. In the subways and trains, bicycles are allowed from Monday to Friday starting at 8:30 pm, on Saturdays starting at $2 \mathrm{pm}$, and on Sundays and holidays during the operation of the stations. Integration on city buses was also made available to users as of November 2016 (São Paulo City Hall, 2020). 


\subsection{Global Scenario}

It can be seen that the prioritization of public transport and the integration of the bicycle with this mode of transport is a reality in several countries. In cities such as Groningen, in the Netherlands, and Beijing, in China, about $50 \%$ of the population uses the bicycle as a means of transportation. In Tokyo, Japan, and Moscow, Russia, a significant portion of the population also uses the bicycle daily (Paiva, 2013). In Brazil, in 2012, only 4\% of commutes in Brazil were made using bicycles, (PlanMob, 2015).

In Copenhagen, considered the best city for cyclists (EXAME, 2015), about 55\% of the population uses the bicycle to go to work or school daily, showing the agility and practicality found in this modal. Countries such as the Netherlands, France, Sweden, Belgium, Spain, Germany, Slovenia, Argentina and Ireland, are also on the list of countries with higher bicycle use.

Recent studies present the advantages of adopting public policies that seek to expand circulation modals in large cities (Bai et al., 2020). An important factor for the success of this type of policy is the convincing of the population (Boufidis et al., 2020) and the encouragement of management - both public and private - to enhance the use of alternative modes of transportation (Almannaa et al., 2021) and circulation of people (Bai et al., 2020; Chen et al., 2021).

\section{Method}

In order to analyze the opinion of a sample of the population who lives or works in the city of São Paulo about the creation and expansion of bike lanes and cycle tracks in the city, we conducted a survey of opinion, with descriptive quantitative characteristic (Fonseca, 2002), with data that can be quantified and analyzed by means of mathematical calculations to explain the causes of the phenomena studied, in order to try to describe the relationship, or not, between the variables used. The opinion survey is used to help companies evaluate the level of quality of the service offered (Rossi \& Slongo, 1998), being also one of the principles for a more effective marketing. In this article, where the level of quality of public transportation is analyzed, one can consider that the "company" is characterized by the public agencies responsible for public transportation and its improvements. 
The applied questionnaire is composed of three sections: introduction, with the purpose of the research; means of transportation in general, including frequency of use and overall satisfaction; statements about bicycle use, questions related to the concept of Public Service Motivation, which in Coursey and Pandey's (2007, p. 548) view, "[...] allows public organizations to operate as efficiently as their private sector counterparts in the production of social services"; finally, demographic questions to identify the respondents' profile complement the questionnaire. All items were measured on a five-point Likert scale $(1=$ very dissatisfied and $5=$ very satisfied $)$.

A pre-test was carried out to evaluate the structure and quality of the formulation of the questions, in order to identify possible adaptations needed for official distribution of the questionnaire (Carvalho \& Feire, 2021). The pre-test was distributed to 10 respondents. Among the suggested changes were the order of the questionnaire sections, leaving the demographic questions to the end, options available in the closed-ended questions to avoid response limitations, and adapted translation of the Public Service Motivation evaluation dimensions.

The adjusted questionnaire was distributed both physically, via printed questionnaires directly to respondents, and electronically, via the Survey Monkey platform, between March 15 and April 28, 2017. The sample used was non-probabilistic by convenience (Malhotra, 2012), in which the questionnaires were made available, in print and online, to residents of São Paulo and on the campus of a public college in Osasco.

For data analysis, we used the technique of mean analysis and linear regression analysis. The main objective of linear regression is to estimate how much of the independent variables (antecedent) explain the variance of the dependent variable (consequent) (Aiken, West, \& Pitts, 2003; Hair et al., 2015), which in our research was the respondent's propensity to use a bicycle as a type of transportation. The analyses were conducted using SPSS software.

\section{Analysis of the results}

This section will present the objective results in the empirical phase of this study.

The sample was composed of 299 respondents, of whom 142 declared themselves female (47.49\%). Most of the participants were between 20 and 30 years old $(n=160 ; 53.51 \%)$, declared to have incomplete higher education $(n=176 ; 58.86 \%)$ and work in a CLT regime $(n=125$; $41.80 \%)$. 


\subsection{Types of transportation}

The first session of the questionnaire aimed to identify how often the types of transportation were used and what was the average evaluation for each mode, based on a general scenario of comfort, cost, speed, and other factors that were not specified (Figure 1).

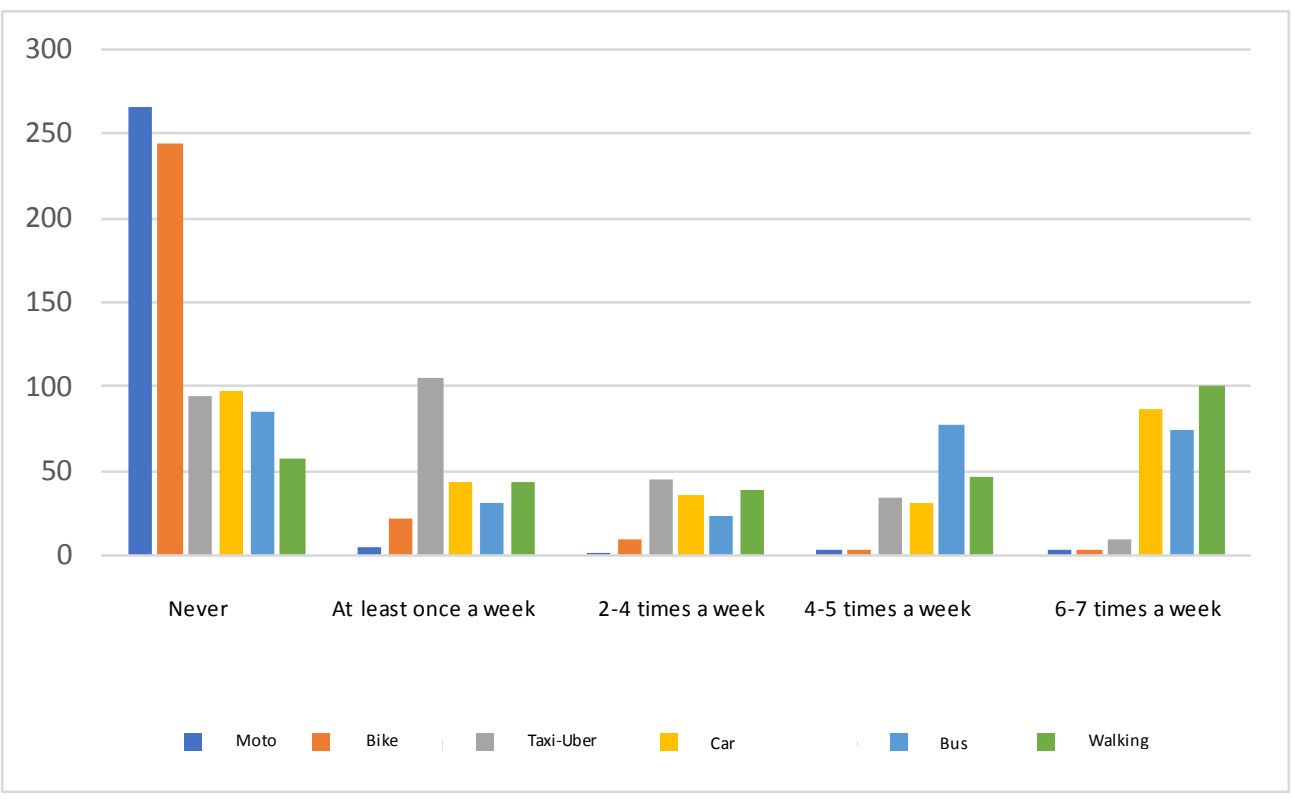

Figure 1. Frequency of Use by Types of Transportation Source; Survey data.

We could observe that the most used means of transportation in this sample is "on foot", followed by "own car" and "bus". Motorcycle and bicycle are the least used means of transportation. Only 37 respondents $(12.37 \%)$ declared that they use the bicycle with some frequency. Most of these respondents, 22 respondents, declared they use it only once a week, and only six respondents declared they use it more than 4 days a week. This data shows that there is still plenty of room for an increase in the number of bicyclists in the city.

The average rating for each mode of transportation (Figure 2). Respondents were also able to include an evaluation of the modes of transportation they did not use, providing insight into how they imagined the use of each mode of transportation was. 


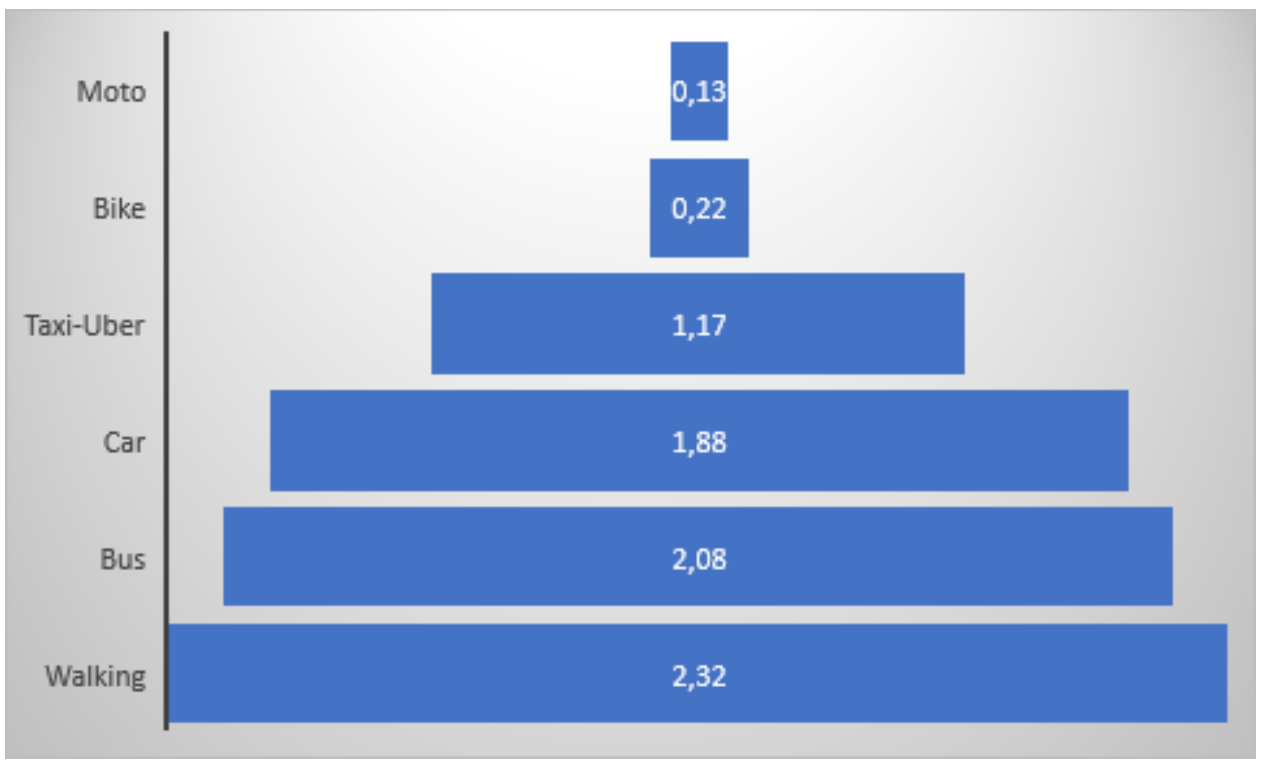

Figure 2. Types of transportation evaluation Source: Survey data.

We then performed a correlation analysis of the evaluation of the means of transportation "Bicycle", with the gender of the respondents. A significant correlation was observed among the respondents who evaluated as "Very Dissatisfied", 35 female respondents, and 26 male respondents. This fact reinforces the indication of Providelo and Sanches (2010) and Bacchieri et al. (2005), that men are more likely to use the bicycle as a means of transportation than women.

We then observed the average evaluation of each means of transportation, by gender (Table 1).

Table 1 - Mean evaluation of the means of transportation by gender

\begin{tabular}{lll}
\hline $\begin{array}{c}\text { Transportation } \\
\text { types' }\end{array}$ & \multicolumn{1}{c}{ Gender } & Means \\
\hline Car & Women & 3.71 \\
\cline { 2 - 3 } & Men & 3.58 \\
\hline Taxi/Uber & Women & 3.81 \\
\cline { 2 - 3 } & Men & 3.67 \\
\hline Bus & Women & 2.51 \\
\cline { 2 - 3 } & Men & 2.57 \\
\hline Motorcycle & Women & 2.24 \\
\cline { 2 - 3 } & Men & 2.30 \\
\hline Bicycle & Women & 2.63 \\
\hline
\end{tabular}




\begin{tabular}{lll}
\hline & Men & 2.81 \\
\hline \multirow{2}{*}{ Walking } & Women & 3.03 \\
\cline { 2 - 3 } & Men & 3.41 \\
\hline
\end{tabular}

\section{Source. Survey data.}

It is possible to see that the average rating for the means of transportation "Bicycle" and "On foot" is higher in male respondents, most likely due to the vulnerability and lack of safety for women in the use of these means of transportation. Oppositely, the modes of transportation "Car" and "Taxi/Uber" were those that received higher average ratings from female respondents.

\subsection{Bicycles}

The second session of the questionnaire was composed of some statements about the evaluation of the bicycle lanes and bike paths policies implemented in the city, reasons for not using bicycles, and statements about propensity to use them. In this session respondents were asked to indicate their level of agreement with the statements. About the policies, the overall average score can be seen in Table 2

\section{Table 2 - Average statement on policy evaluation}

\begin{tabular}{lc}
\hline Statements & Means \\
\hline The increase of cycle lanes was very well implemented in the city & 2.94 \\
\hline The increa se of bicycle lanes was very well implemented in the city & 2.81 \\
\hline The bike lanes/cycle paths increased safety for cyclists & 3.54 \\
\hline The bike paths/cycle lanes disrupted car traffic & 2.65 \\
\hline Cycle lanes have increased the amount of people using bicycles as a type of transportation & 3.77 \\
\hline The bike paths/cycle lanes have improved the urban mobility of the city & 2.86 \\
\hline I feel comfortable using the bike lanes in the city & 2.72 \\
\hline I believe that bike lanes a re highly used & 2.29 \\
\hline I believe that the increase in bike lanes does not make more people use bicycles & 4.16 \\
\hline I believe that the city needs more actions to increase the number of cyclists & 3.63 \\
\hline I would be more satisfied with bike lanes if there was public consultation prior to implementation
\end{tabular}

\section{Source: Survey data.}


Observing the statements with the highest average, we can conclude that most respondents agree that the bike lanes and bike paths created by the city government have increased the number of cyclists in the city, also bringing more safety for them. Even so, it is necessary to continue implementing actions that encourage the use of this means of transportation. Likewise, most respondents indicated that they would feel more satisfied if there was a public consultation before the implementation of bike lanes/cycling paths, based on the opinion of the population that uses the bicycle or ends up being somehow impacted by these changes.

The t-test, having as independent variables the gender and age of respondents, and Post Hoc Test, for correlation of evaluation with income and education, did not show relevant statistical significance. Thus, it is possible to conclude that the concordances for the statements above do not depend on the gender, age, income or education of the citizen.

Observing the statements with the highest average, it can be concluded that most respondents agree that the bike paths and lanes created by the city government have increased the number of cyclists in the city, also bringing more safety for them. Even so, it is necessary to continue implementing actions that encourage the use of this means of transportation. Likewise, most respondents indicated that they would feel more satisfied if there was a public consultation before the implementation of bike lanes/cycling paths, based on the opinion of the population that uses the bicycle or ends up being somehow impacted by these changes.

The t-test, having as independent variables the gender and age of respondents, and Post Hoc Test, for correlation of evaluation with income and education, did not show relevant statistical significance. Thus, it is possible to conclude that the concordances for the statements above do not depend on the gender, age, income or education of the citizen.

As for the reasons for not using the bicycle, most answers indicate that the main factors, among those used in the questionnaire, that prevent the use of a bicycle are distance, topography, and fear, in that order (Table 3). This analysis reinforces the idea that integrations with other means of transportation, especially public transportation such as subways, trains and buses, would be a great facilitator and motivator to increase the use of the bicycle as a type of transportation. 
Table 3 Average rating for reasons for non-use

\begin{tabular}{lc}
\hline Statements & Means \\
\hline I don't use a bicycle to work because of the distance & 3.68 \\
\hline I don't use a bicycle to work because of the terrain & 3.39 \\
\hline I don't use a bicycle to work because my workplace does not offer a dressing room and/orbike & 2.82 \\
rack & 2.51 \\
\hline I don't use a bicycle to work because I am not physically fit & 3.24 \\
\hline I don't use a bicycle to work because I am afraid & 2.69 \\
\hline I don't use a bicycle to work because I find it uncomfortable & 2.62 \\
\hline I don't use a bicycle to work because it is a time-consuming means of transportation & \\
\hline
\end{tabular}

Source: Survey data.

The fear factor needs to be studied in more detail, in order to understand if the feeling of insecurity on bicycle paths reflects the fear of being vulnerable and subjected to theft and assaults or risks of accidents and pedestrian collisions. In any case, this insecurity can be mitigated by improving the quality of roads, either by constant maintenance of bike lanes and cycle tracks, signs and aw areness both for cyclists, pedestrians, and drivers of motorized means of transportation, in addition to strengthening security by public officials.

The last part of the questionnaire had two statements about propensity to bicycle (Table 4). There was no significant correlation between the reasons for non-use and propensity to use with the opinion about bike lane policies. However, it can be assumed that the average of 3.15 reiterates the need for the creation of integration services with other means of transportation as a way to increase the number of cyclists.

\section{Table 4 - Mean agreement for propensity to use bicycles}

\begin{tabular}{ll}
\hline Statements & Means \\
\cline { 2 - 2 } I would replace my current mode of transportation to get to work by bicycle & 2.72 \\
\hline I would use a bicycle to work if there was integration with bus/subway & 3.15 \\
\hline
\end{tabular}

Source: Survey data. 


\subsection{Motivation for public services}

The third section of the questionnaire was composed of statements related to motivation to use public services (Public Service Motivation) proposed by Perry (1996), in which the respondent should indicate the level of agreement for each statement on a 5-point Likert-type scale (ranging from strongly agree to strongly disagree).

After analyzing the homoscedasticity of the distribution (Levene's test), absence of mulinearity (variance inflation factor - VIF), we conducted the multiple linear regression (Hair et al., 2015).

Furthermore, at the end of the regression analysis, we analyzed the distribution of residuals, checking their normality (Aiken, West, \& Pitts, 2003).

To assess which variables explained the respondents' intention to use bicycles as a means of transportation, a multiple linear regression analysis was performed. This statistical model aims to assess whether a linear function of explanatory independent variables explains a dependent variable (Hoffman, 2016).

The estimated linear regression model considered demographic variables - gender, income, and age of respondents - and satisfaction with the most used mode of transportation (SAT_Transp), overall evaluation of the bicycle lanes implementation program (AVAL_Ciclo), and personal motivation to join public services (MOT_Publ) as independent variables. Propensity to use bicycles was the selected dependent variable (aggregate mean of the two items presented in Table 4). The results are presented in Table 5.

Table 5 - Multiple linear regression

\begin{tabular}{lcllll}
\hline \multicolumn{1}{c}{ Independent Variable } & $\mathrm{B}$ & Standardized Error & $\beta$ & $t$ & $p$-value \\
\hline \hline$(\beta 0)$ & $-1,494$ & 0,866 & & $-1,724$ & 0,086 \\
age & 0,014 & 0,012 & 0,085 & 1,199 & 0,232 \\
income & 0,000 & 0,000 & 0,080 & 1,152 & 0,251 \\
gender & 0,171 & 0,184 & 0,058 & 0,928 & 0,354 \\
satisfaction with transportation & $-0,040$ & 0,133 & $-0,019$ & $-0,301$ & 0,764 \\
Bicycle path evaluation & 0,804 & 0,179 & 0,292 & 4,487 & 0,000 \\
Motivation to use public services & 0,300 & 0,163 & 0,120 & 1,838 & 0,067 \\
\hline
\end{tabular}

\footnotetext{
Dependent Variable: Bicycle use propensity

$\mathrm{R}^{2}=0,128$ and $\mathrm{R}^{2}$ adjusted $=0,115$
} 
As can be seen in Table 5, only the variables evaluation of the bicycle lanes implementation program $(\beta=0.292 ; \mathrm{t}=4.487 ; \mathrm{p}<.01)$ and motivation to use public services $(\beta$ $=0.120 ; \mathrm{t}=1.838 ; \mathrm{p}<.10$ ) were significant in explaining the propensity to use bicycles as a means of commuting stated by the sample $\left(\mathrm{R}^{2}\right.$ adjusted $\left.=11.5 \%\right)$.

\section{Discussion}

The purpose of this study was to analyze the opinion of a sample of the population about policies to encourage bicycle use in the city of São Paulo. It was possible to conclude that most respondents agree that there is a need for more public actions similar to those that were implemented and already addressed in this study, and that the result of these actions brings more safety and increases the number of bicyclists.

Also according to the data obtained in the sample, it was highlighted the need for public consultation before the implementation of new bike lanes. Which means that the population initially approves measures that improve urban mobility, not only for those transports already commonly and most frequently used. The great impediment to the acceptance and as a consequence, directly or indirectly, adoption of these policies is the feeling of lack of involvement in the process, where especially the negative impacts, are not measured and previously exposed to the population.

As seen in previous studies (Sener, Eluru, \& Bhat, 2009), the assessment of bicycle use is positive by much of the population, even by those who did not indicate a propensity to ad opt this type of transportation.

It was confirmed, in this sample, that there is a relationship between the increase of bike lanes with the amount of cyclists in the city and the perception of this change. According to IBOPE, between 2012 and 2015, the amount of frequent bicycle users, i.e., individuals who use them almost every day, varied between $2 \%$ and $3 \%$ of the population. Although in the total population this variation is low, if we compare the increase from one year to another, the relevance is greater, so that in 2013 the city had 174.1 thousand cyclists and in 2014 this number reached 261 thousand, an increase of almost $50 \%$ in the total amount (IBOPE, 2014). As for the perception of increased number of cyclists, the results indicate that most respond ents see a relationship between the increase in bicycle lanes and cycle tracks, with the increase in the number of cyclists, so that this statement was the second with the highest identified agreement. 
Among the main reasons for not using the bicycle, fear and difficulties due to the distance and relief of the city are the main factors that still cause few people to use the bicycle. This result is in line with the result of the IBOPE (2015) survey, which also identified that, where $44 \%$ of respondents said that increasing the safety of cyclists would make them use the bicycle. In 2014 this number was $26 \%$, which shows that some people are more inclined to adopt this means of transportation if this improvement occurs. Still linked to safety, $18 \%$ of the respondents answered that the increase in street signs would also make them use the bicycle for commuting. This number is 5\% higher than the one registered in 2013.

Regarding distance and relief, still according to IBOPE (2015), 13\% of respondents said that the construction of more bike lanes connecting the city would be a relevant factor for them to use the bicycle as a means of transportation. In 2014, this number was $26 \%$. This drop can be related to the increase in the number of bike lanes and cycle tracks in this period. In addition, in $2015,11 \%$ of respondents said that the construction of bike racks and bike parks integrated with public transportation would be relevant for bicycle use. In 2014 this figure was $6 \%$.

The relationship between the population's acceptance of policies that encourage bicycling and personal motivation for public services was confirmed. The more the population is aware of and makes use of public services, the easier it is for them to accept new changes in public policies in general.

It was also possible to verify that, like studies conducted in other countries (Boufidis et al., 2020 and Chen et al, 2021), convincing the population of the benefits of adopting public policies related to urban mobility is fundamental to increase the propensity to use these modes.

\section{Final considerations}

The main aspect for the population of the city of São Paulo not to acquire the bicycle as a means of transportation is the perceived lack of safety. The relief of the city and the great distances that are traveled daily were also shown as impediments. Even so, for the population of classes D and E, the bicycle has a relevant presence among the most used means of transportation. The research did not show significance for socio demographic factors. 


\subsection{Theoretical contributions}

The main theoretical contribution of this paper is the significant relationship between the acceptance of measures implemented to expand and create bicycle lanes and the motivation for public services, bringing a new insight that can be used in the design of public policies that bring significant impact to the population.

These results can be used to direct and facilitate the thinking of public policies aimed not only at the expansion of the bicycle network in the city of São Paulo, but for other cities that may be facing the same scenario, and for policies related to urban mobility in general that aim to improve the chaotic situation faced by the population today. It is understood, therefore, that the theoretical contribution of the study was to bring a new relationship between the acceptance of public policies, which is not directly related to socio-demographic data, but rather to the motivation for public services.

\subsection{Contributions for managers}

As a contribution for managers, the awareness of public services and the rationales for the implementation of new public policies, could help increase the critical thinking of the population regarding the services that are offered to everyone.

In this way, future mayors, or politicians in general, who have within their reach the possibility of implementing new public policies, can make use of the result of this work, by providing more knowledge of the public services offered, through commercials in prime time on broadcast TV, for example.

In addition, bringing new measures to the agenda that may have a relevant impact on the general population, so that people feel that their opinion has been expressed, may facilitate the acceptance of these policies once they are implemented. It is understood that the population will not always express its opinion with an overall view, but basing the choices that led to the decision to implement public policies on statistical data could also be a useful tool to ensure greater acceptance.

Future researches can analyze other cities, with the same scenario of public policy implementation aimed at increasing bicycle use. Even in São Paulo, new surveys can be done using another type of sample and a larger number of respondents. The comparison can also be made with other countries, identifying how they manage their mobility plans, in order to 
identify the profile and level of knowledge of people regarding the public services offered and if there is a relationship between this knowledge and the acceptance of the public policies implemented.

\subsection{Limitations and suggestions for future studies.}

Like all academic works, this study presents some limits that can be mitigated in future research. The first, is the endogenous aspect of collecting in only one capital city. Future studies can make use of national probability samples as a way to understand the evaluation of mobility programs in a holistic way.

Another limit of this study was not controlling for the political party orientation of the respondent. Evidently, this individual characteristic can influence the pattern of responses. Therefore, it is recommended that further studies control for this variable as a way to mitigate a possible bias.

\section{References}

Aiken, L. S., West, S. G., \& Pitts, S. C. (2003). Multiple linear regression. Handbook of psychology, 481-507.

Almannaa, M. H., Ashqar, H. I., Elhenawy, M., Masoud, M., Rakotonirainy, A., \& Rakha, H. (2021). A comparative analysis of e-scooter and e-bike usage patterns: Findings from the City of Austin, TX. International Journal of Sustainable Transportation, 15(7), 571-579. https://doi.org/10.1080/15568318.2020.1833117

Associação Nacional das Empresas de Transportes Urbanos. (2006). Pesquisa Mobilidade da População Urbana. Recuperado em 10, Maio, 2020 de http://urbana-pe.com.br/wpcontent/uploads/2010/03/Mobilidade_da_Populacao_Urbana.pdf

Bacchieri, G., Gigante, D. P., \& Assunção, M. C. (2005). Determinantes e padrões de utilização da bicicleta e acidentes de trânsito sofridos por ciclistas trabalhadores da cidade de Pelotas, Rio Grande do Sul, Brasil. Cadernos de Saúde Pública, 21(5), 1499-1508. https://doi.org/10.1590/S0102-311X2005000500023

Bai, L., Sze, N. N., Liu, P., \& Haggart, A. G. (2020). Effect of environmental awareness on electric bicycle users' mode choices. Transportation research part D: transport and environment, 82, 102320. https://doi.org/10.1016/.trd.2020.102320

Boufidis, N., Nikiforiadis, A., Chrysostomou, K., \& Aifadopoulou, G. (2020). Development of a station-level demand prediction and visualization tool to support bike-sharing systems' 
operators. Transportation $\quad$ Research $\quad$ Procedia, 47, 51-58. https://doi.org/10.1016/j.trpro.2020.03.072

Carvalho, M., \& Freire, O. (2021). Efeito do Apelo À Escassez sobre a Intenção de Compra. Retail Management Review, 1(1), e2-e2. https://doi.org/10.53946/rmr.v1i1.2

Companhia de Engenharia de Tráfego - CET. (2020). Mapa de Infraestrutura cicloviária. Recuperado em 22, Maio, 2020 de http://www.cetsp.com.br/consultas/bicicleta/mapa-d einfraestrutura-cicloviaria.aspx

Chen, C. F., Chen, Y. X., Mu, P. J., \& Yu, Y. H. (2021). Beyond adoption of shared bike: A case study on antecedents and consequences of brand attachment in Taiwan. Research in $\begin{array}{llll}\text { Transportation } \quad \text { Business \& } \quad \text { Management, } & \text { 40, }\end{array}$ https://doi.org/10.1016/j.rtbm.2020.100574

Chen, W., Liu, Q., Zhang, C., Mi, Z., Zhu, D., \& Liu, G. (2020). Characterizing the stocks, flows, and carbon impact of dockless sharing bikes in China. Resources, Conservation and Recycling, 162, 105038. https://doi.org/10.1016/j.resconrec.2020.105038

Coursey, D. H., \& Pandey, S. K. (2007). Public service motivation measurement: Testing an abridged version of Perry's proposed scale. Administration \& Society, 39(5), 547-568. https://doi.org/10.1177/0095399707303634

EXAME. (2015). As 15 melhores cidades do mundo para and ar de bicicleta. Recuperado em 20, Maio, 2020 de https://exame.com/mundo/as-15-melhores-cidades-do-mundo-paraandar-de-bicicleta/

Fabris, J., Bernardy, R. J., Sehnem, S., \& Piekas, A. A. S. (2020). Cidades Sustentáveis: Caminhos e Possibilidades. International Journal of Professional Business Review, 5(2), 214-233. https://doi.org/10.26668/businessreview/2020.v5i1.160

Field, A. (2009). Descobrindo a Estatística Usando o SPSS-5. 2 ed. Bookman.

Freitas, P. V. N., da Silveira, J. A. R., da Silva, G. J. A., \& da Silva, D. C. (2015). Mobilidade urbana sustentável: problemas e soluções. Revista Científica ANAP Brasil, 8(12). https://doi.org/10.17271/1984324081220151134

Hair, J. F., Black, W. C., Babin, B. J., \& Anderson, R. E. (2015). Multivariate data analysis. Tamil Nadu.

Goldsmith, S. (1992). Reasons Why Bicycling and Walking Are Not Being Used More Extensively As Travel Modes. Federal Highway Administration, Publication No (Vol. 1). FHWA-PD-92-041, National Bicycle and Walking Study: Case Study.

Instituto Brasileiro de Opinião e Estatística - IBOPE. (2014). 87\% dos paulistanos são a favor da construção e ampliação das ciclovias em São Paulo. Recuperado em 20, Maio, 2020 https://www.ibopeinteligencia.com/noticias-e-pesquisas/87-dos-paulistanos-sao-a-favorda-construcao-e-ampliacao-de-ciclovias-em-sao-paulo/ 
Instituto Brasileiro de Opinião e Estatística - IBOPE. (2015). Deslocamentos por ônibus ou a pé são os mais utilizados para realização das atividades rotineiras. Recuperado em 20 , Maio, $2020 \mathrm{de}$ https://www.ibopeinteligencia.com/noticias-e-pesquisas/deslocamentospor-onibus-ou-a-pe-sao-os-mais-utilizad os-para-realizacao-das-atividades-rotineiras/

Lopes, J. R., \& Santos, F. de A. (2020). Research on the most relevant aspects to select a house in the city of são paulo under the residents' point of view. International Journal of Professional Business Review, 5(2), 179-193. https://doi.org/10.26668/businessreview/2020.v5i1.167

Malhotra, N. (2012) Pesquisa De Marketing: Uma Orientação Aplicada. Bookman, 6a Edição.

Mao, G., Hou, T., Liu, X., Zuo, J., Kiyawa, A. H. I., Shi, P., \& Sandhu, S. (2021). How can bicycle-sharing have a sustainable future? A research based on life cycle assessment. $\begin{array}{llll}\text { Journal of Cleaner } & \end{array}$ https://doi.org/10.1016/j.jclepro.2020.125081

Ministério das Cidades. (2015). Secretaria Nacional de Transporte e da Mobilidade Urbana. Caderno de Referência para Elaboração de Plano de Mobilidade Urbana: PlanMob construindo a cidade sustentável. Recuperado em 10, Maio, 2020 de http://www.cidades.gov.br/images/stories/ArquivosSE/planmob.pdf

Oja, P., Titze, S., Bauman, A., De Geus, B., Krenn, P., Reger-Nash, B., \& Kohlberger, T. (2011). Health benefits of cycling: a systematic review. Scandinavian Journal of medicine \& Science in sports, 21(4), 496-509. https://doi.org/10.1111/j.1600-0838.2011.01299.x

Olekszechen, N., Battiston, M., \& Kuhnen, A. (2016). Uso dabicicleta como meio de transporte nos estudos pessoa-ambiente. Desenvolvimento e Meio ambiente, 36. https://doi.org/10.5380/dma.v36i0.43654

Paiva, M. D. (2013). Fatores que influenciam no uso da bicicleta de forma integrada com o metrô.

Perry, J. (1996). Measuring public service motivation: An assessment of construct validity. Journal of Public Administration Research and Theory,6, 5-22. https://doi.org/10.1093/oxfordjournals.jpart.a024303

Providelo, J. K., \& da Penha Sanches, S. (2010). Percepções de indivíduos acerca do uso da bicicleta como modo de transporte. Transportes, 18(2). https://doi.org/10.14295/transportes.v18i2.424

Rojas-Rueda, D. (2021). Health impacts of urban bicycling in Mexico. International Journal of Environmental Research And Public Health, 18(5), 2300.

Rossi, C. A. V., \& Slongo, L. A. (1998). Pesquisa de satisfação de clientes: o estado-da-arte e proposição de um método brasileiro. Revista de Administração contemporânea, 2(1), 101 125. https://doi.org/10.1590/S1415-65551998000100007

Scaringella, R. S. (2001). A crise da mobilidade urbana em São Paulo. São Paulo em perspectiva, 15(1), 55-59. https://doi.org/10.1590/S0102-88392001000100007 
Sener, I. N., Eluru, N., \& Bhat, C. R. (2009). An Analysis of Bicyclists and Bicycling Characteristics: Who, Why, and How Much are they Bicycling? Forthcoming. Transportation Research Record. https://doi.org/10.3141/2134-08

Teschke, K., Reynolds, C. C., Ries, F. J., Gouge, B., \& Winters, M. (2012). Bicycling: Health risk or benefit. UBC Med J, 3(2), 6-11.

\section{Contribution of authors}

Every author should account for at least one component of the work. Paper approved for publication need to specify the contribution of every single author.

\begin{tabular}{|c|c|c|c|}
\hline Contribution & [Author 1] & [Author 2] & [Author 3] \\
\hline 1. Definition of research problem & $\sqrt{ }$ & & $\sqrt{ }$ \\
\hline $\begin{array}{l}\text { 2. Development of hypotheses or research questions (empirical } \\
\text { studies) }\end{array}$ & $\sqrt{ }$ & & $\sqrt{ }$ \\
\hline $\begin{array}{l}\text { 3. Development of theoretical propositions } \\
\text { (theoretical work) }\end{array}$ & $\sqrt{ }$ & $\sqrt{ }$ & $\sqrt{ }$ \\
\hline 4. Theoretical foundation / Literature review & $\sqrt{ }$ & $\sqrt{ }$ & $\sqrt{ }$ \\
\hline 5. Definition of methodologicalprocedures & $\sqrt{ }$ & & \\
\hline 6. Data collection & & & $\sqrt{ }$ \\
\hline 7. Statistical a nalysis & $\sqrt{ }$ & & $\sqrt{ }$ \\
\hline 8. Analysis and interpretation of data & $\sqrt{ }$ & & $\sqrt{ }$ \\
\hline 9. Critical revision of the manuscript & $\sqrt{ }$ & $\sqrt{ }$ & $\sqrt{ }$ \\
\hline 10. Manuscript writing & $\sqrt{ }$ & $\sqrt{ }$ & $\sqrt{ }$ \\
\hline 11. Other (please specify) & & & \\
\hline
\end{tabular}

